\title{
Effect of Mucous, Blood and Bacterial Contamination at the Time of Embryo Transfer, and it's Impact on the IVF Pregnancy Outcome
}

\author{
Shehata M, Mohammed El Sokkary* and Hassan EA \\ International Islamic Center for Population Studies and Research, Al-Azhar University, USA
}

Submission: August 24, 2017; Published: September 26, 2017

*Corresponding author: Mohammed El Sokkary, International Islamic Center for Population Studies and Research, Al-Azhar University, USA, Email: mohammedelsokkary1@yahoo.com

\begin{abstract}
Objective: The aim of this study is to investigate whether the presence of mucous, blood and microorganisms, as detected on catheters used for ET alters the outcome of IVF-ET.

Patients and Methods: Design: Prospective analysis. Setting: The assisted reproduction unit of C PLAS - Hospital in Sana'a Yemen. Eighty one (81) controlled ovarian hyperstimulation ( $\mathrm{COH}$ ) cycles performed for IVF-ET. Intervention(s): The mucous and blood on the tips of catheters used for ET were subjected to culture and sensitivity. Main Outcome Measure(s): Pregnancy and implantation rates.

Results: Mean age 32.36 years, mean \pm SD of collected oocytes $12.275 \pm 6.015$, mean \pm SD of transferred embryos $3.38 \pm 0.71$, classified into : Positive Culture group (31) negative culture group (50), other classification presence of blood or not and presence of mucous or not. all data on patients, $\mathrm{COH}$, and embryology were similar in culture groups, clinical and ongoing pregnancy rates as well as implantation rates were no significantly difference in the positive culture group and the negative culture group (p value 0.594), pregnancy rate according to presence of blood in embryo transfer(ET) catheter there are significant increase in pregnancy and implantation rat in negative blood in ET catheter ( $p$ value 0.839), pregnancy and implantation rate in presence of mucous in ET catheter no significant difference ( $p$ value 0.456), the type of bacteria which present in contaminated group. Cultures were positive, predominantly for Escherichia coli (64\%) and Streptococcus species $(80 \%)$.
\end{abstract}

Conclusion: The presence of bacterial contamination of catheter tips during embryo transfer does not significantly affect the cycle outcomes due to presence of mucous in cervical canal prevent ascending microorganism to endometrial cavity and avoid rough touched cervical canal and endometrium to avoid bleeding.

Keywords: Bacteria; Mucous; Blood

Abbreviation: $\mathrm{COH}$ : Controlled Ovarian Hyperstimulation; ARTs: Assisted Reproductive Techniques; ICSI: Cytoplasmic Sperm Injection; GnRH: Gonadotropin-Releasing Hormone; HCG: Human Chorionic Gonadotropin; COH: Controlled Ovarian Hyperstimulation; ET: Embryo Transfer; ASRM: American society of Reproductive Medicine, ESHRE: European Society for Human Reproduction and Embryology, MEFS: Middle East Fertility Society, MSRM: Mediterranean Society for Reproductive Medicine

\section{Introduction}

Assisted reproductive techniques (ARTs), such as transvaginal oocyte pick-up and catheter insertion for intrauterine insemination or embryo transfer, are considered to be relatively safe procedures [1]. In general, acute pelvic infection following ARTs is generally uncommon despite the invasive nature of such procedures [2-3]. Any risk of infection arises from the transfer of microorganisms that make up the normal vaginal flora to the uterine cavity and pelvic peritoneum. The fear that genital

bacterial contamination may interfere with embryo implantation has been suggested [4]. Clinical studies have shown that bacterial contamination of the embryo transfer catheter has a significant negative effect on the clinical pregnancy rates [5-8]. In addition, cervical sterility at the time of ART procedures cannot be achieved with the routine use of vaginal antiseptics since there is evidence these solutions have been shown to have a negative impact on the quality of the oocytes collected and the embryos 
available for transfer [9]. Moreover, there is insufficient evidence about the effects of different antibiotic prophylaxis regimens on ART cycle outcomes [8,10-12]. The purpose of this study was to evaluate the rate of bacterial contamination of cervical mucus samples from women at the time of embryo transfer. In addition, the rate of bacterial contamination of catheters following embryo transfer, as well as the outcomes of ART cycles with regards different levels of contamination was determined.

\section{Patients and Methods}

This prospective clinical trial study was carried out on eighty one (81) controlled ovarian hyperstimulation $(\mathrm{COH})$ cycles scheduled for IVF-ET at The assisted reproduction unit of C PLAS - Hospital in Sana'a Yemen from July 2012 to March 2013. All couples were subjected to detailed explanation about the procedure. All cases were clinically evaluated. A full general and local examination of both couples was done. Routine investigations and hormonal assays were requested according to our unit protocol. Study includes eighty one couples; female aged 25-40 years undergoing intra cytoplasmic sperm injection (ICSI) cycle from January 2014 to December 2015. Inclusion criteria set namely, 2-20 years of infertility, having minimum five Oocytes at Oocytes pick up, endometrial thickness of $8 \mathrm{~mm}$ and more indicating good ovarian response, having normal uterine cavity and basal follicle-stimulating hormone (FSH) $(<10 \mathrm{mIU} / \mathrm{ml})$.

Patients were put on long protocol, gonadotropin-releasing hormone (GnRH)-agonists started on cycle Day 21 daily doses given subcutaneously till Day 3 of next cycle. Hormonal evaluation: Serum FSH, luteinizing hormone (LH), Estradiol (E2) and transvaginal sonography was done on Day 3 to confirm down regulation. Induction with recombinant FSH ( $\mathrm{rFSH}$ ) was started once pituitary down regulation was confirmed. The dose schedule was modified according to parameters like body mass index (BMI), previous response and ovarian reserve estimates and was given for four days (Day 3-6). Follicular monitoring was initiated on Day 7 of cycle and further doses of rFSH were given according to follicle size and continued till Day 11. Women were scheduled for Oocytes retrieval when at least five follicles reached $18 \mathrm{~mm}$ size and injection human chorionic gonadotropin (HCG) 10,000 IU was given.

Transvaginal sonography guided Oocytes retrieval was then planned 36 hours after HCG, which was performed under short general anesthesia. The retrieved Oocytes were then incubated for 1 hour in global fertilization media and then, depending on maturity of Oocytes, ICSI was performed. Denudation of Oocytes was carried out chemically \&mechanically before ICSI was performed. Oocytes were incubated overnight in global total media in a triple gas incubator (Labotect) and observed after 16-18 hours post insemination for fertilization. The fertilized Oocytes were then transferred into a cleavage medium and incubated. All transfers were performed using Labotect catheter.

\section{Culture Samples}

\section{Cervical sample (pre-transfer)}

A sterile cusco speculum was inserted into the vagina and opened so that the external os is visualized. Using a sterile insulin syringe, the cervical mucus and secretions were aspirated. The aspirated secretions were placed onto a $5 \%$ sheep blood agar plate. The plates were incubated aerobically and under 5\% CO2 at $37^{\circ} \mathrm{C}$ for $72 \mathrm{~h}$.

\section{Catheter tip sample (post-transfer)}

The vagina and cervix were cleaned with normal saline or culture media (no antiseptic solution was used) and the patient prepared for the embryo transfer. Any apparent vaginal and cervical secretions were removed using sterile cotton swabs. All embryos were transferred using the same catheter type, using a non-touch sterile replacement technique (sterile drapes, speculum and disposable non-latex gloves). Contact between the transfer catheter, the vaginal walls and ectocervix was avoided. Following withdrawal of the catheter, and confirmation that the embryos had been transferred, the embryologist cut off the distal $2 \mathrm{~cm}$ of the catheter tip using sterile scissors. Each individual tip was rolled on to a $5 \%$ sheep blood agar plate, using sterile forceps. The plates were incubated aerobically and under $5 \%$ $\mathrm{CO} 2$ at $37^{\circ} \mathrm{C}$ for $72 \mathrm{~h}$.

\section{Microbiological Assessment}

The plates and broth solution were incubated aerobically at $37{ }^{\circ} \mathrm{C}$ for $48 \mathrm{~h}$. Following the incubation period, a single microbiologist, blinded to the randomization allocation, performed the microbiological assessment of the plates. Bacteria were identified by standard laboratory techniques [13] and quantified using a semi-quantitative four point grading system for gram-positive and gram negative organisms: the absence of growth after $48 \mathrm{~h}$ [no growth (NG)], <10 bacterial colonies $(+),>10$ bacterial colonies $(++)$ and semi-confluent or confluent growth $(+++)$ on the blood agar plate. Positive Brain Heart Infusion (BHI) cultures were plated out, and the bacteria identified. Luteal support was given in form of micronized vaginal progesterone in a dose of $200 \mathrm{mg}$ thrice-daily for 18 days post retrieval. Serum B-HCG was performed on Day 15 following embryo transfer and if positive then transvaginal sonography was performed 15 days later to detect and confirm intrauterine pregnancy.

\section{Statistical Analysis}

Data are presented as means \pm standard deviation. For statistical analysis the $\chi 2$ and Fisher's exact tests were used. Statistical significance was set at $\mathrm{p}<0.05$.

\section{Results}

This randomized, prospective study was conducted on eighty one (81) controlled ovarian hyperstimulation ( $\mathrm{COH}$ ) cycles scheduled for IVF-ET at The assisted reproduction unit of C PLAS 


\section{Global Journal of Reproductive Medicine}

- Hospital in Sana'a Yemen from July 2012 to March 2013 all data on patients, $\mathrm{COH}$, and embryology were similar in all groups, clinical and ongoing pregnancy rates as well as implantation rates were no significantly difference in the positive culture group and the negative culture group $(58.06 \%$ versus $52.0 \%$, $\mathrm{p}$ value 0.594 ), pregnancy rate according to presence of blood in embryo transfer (ET) catheter there are significant increase in pregnancy and implantation rat in negative blood in ET catheter $(16.00 \%$ versus $53.57 \% \mathrm{p}$ value 0.839$)$, pregnancy and implantation rate in presence of mucous in ET catheter no significant difference ( $60.86 \%$ versus $51.72 \%$ p value 0.456 ), the type of bacteria which present in contaminated group. Cultures were positive, predominantly for Escherichia coli (64\%) and Streptococcus species (80\%) (Table 1-5).

Table 1: Contain mean collecting oocyts and mean transferred embryos.

\begin{tabular}{|c|c|}
\hline $\mathrm{M} \pm \mathrm{SD}$ of collected oocytes & $12.275 \pm 6.015$ \\
\hline $\mathrm{M} \pm \mathrm{SD}$ of Transferred embryos & $3.38 \pm 0.712$ \\
\hline
\end{tabular}

Table 2: Pregnancy rate in both groups as regarding of positive bacteria and negative bacteria according to age of women shown no significant result ( $p$ value 0.594 ).

\begin{tabular}{|c|c|c|c|c|}
\hline \multirow{2}{*}{ P value } & \multicolumn{3}{|c|}{ Pregnancy Rate (\%) } & \multirow{2}{*}{ Age (Yr) } \\
\cline { 2 - 4 } & Total & $\begin{array}{c}\text { Negative } \\
\text { bacteria in } \\
\text { ET catheter }\end{array}$ & $\begin{array}{c}\text { Positive } \\
\text { bacteria in } \\
\text { ET catheter }\end{array}$ & \\
\hline \multirow{2}{*}{0.349} & $\begin{array}{c}13 / 23 \\
(56.52)\end{array}$ & $9 / 14(64.28)$ & $4 / 9(44.44)$ & $20-25$ \\
\hline 0.157 & $\begin{array}{c}18 / 36 \\
(50.00)\end{array}$ & $\begin{array}{c}10 / 24 \\
(41.66)\end{array}$ & $8 / 12(66.66)$ & $26-30$ \\
\hline 0.937 & $\begin{array}{c}13 / 22 \\
(59.09)\end{array}$ & $7 / 12(58.33)$ & $6 / 10(60.00)$ & \multirow{2}{*}{$31-38$} \\
\hline 0.594 & $\begin{array}{c}44 / 81 \\
(54.32)\end{array}$ & $\begin{array}{c}26 / 50 \\
(52.00)\end{array}$ & $\begin{array}{c}18 / 31 \\
(58.06)\end{array}$ & \multirow{2}{*}{ Total } \\
\hline
\end{tabular}

Table 3: Pregnancy rate according to presence of blood in embryo transfer catheter there are significant increase in pregnancy and implantation rat in negative blood in ET catheter ( $p$ value 0.839 ).

\begin{tabular}{|c|c|c|c|c|}
\hline \multirow[b]{2}{*}{$P$ value } & \multicolumn{3}{|c|}{ Pregnancy Rate (\%) } & \multirow{2}{*}{ Age (Yr) } \\
\hline & Total & $\begin{array}{l}\text { Negative } \\
\text { Blood in ET } \\
\text { catheter }\end{array}$ & $\begin{array}{l}\text { Positive } \\
\text { Blood in ET } \\
\text { catheter }\end{array}$ & \\
\hline 0.859 & $\begin{array}{c}13 / 23 \\
(56.52)\end{array}$ & $\begin{array}{c}10 / 18 \\
(55.55)\end{array}$ & $3 / 5(60.00)$ & $20-25$ \\
\hline 0.137 & $\begin{array}{c}18 / 36 \\
(50.00)\end{array}$ & $\begin{array}{c}11 / 26 \\
(42.30)\end{array}$ & $7 / 10(70.00)$ & $26-30$ \\
\hline 0.096 & $\begin{array}{c}13 / 22 \\
(59.09)\end{array}$ & $9 / 12(75.00)$ & $4 / 10(40.00)$ & $30-38$ \\
\hline 0.839 & $\begin{array}{c}44 / 81 \\
(54.32)\end{array}$ & $\begin{array}{c}30 / 56 \\
(53.57)\end{array}$ & $\begin{array}{c}14 / 25 \\
(16.00)\end{array}$ & Total \\
\hline
\end{tabular}

Table 4: pregnancy and implantation rate in presence of mucous in ET catheter no significant difference ( $p$ value 0.456 ).

\begin{tabular}{|c|c|c|c|c|}
\hline \multirow{2}{*}{ P value } & \multicolumn{3}{|c|}{ Pregnancy Rate (\%) } & \multirow{2}{*}{ Age (Yr) } \\
\cline { 2 - 4 } & Total & $\begin{array}{c}\text { Negative } \\
\text { Mucous in } \\
\text { ET catheter }\end{array}$ & $\begin{array}{c}\text { Positive } \\
\text { Mucous in } \\
\text { ET catheter }\end{array}$ & \\
\hline 0.34 & $\begin{array}{c}13 / 23 \\
(56.52)\end{array}$ & $8 / 16(50.00)$ & $5 / 7(71.42)$ & $20-25$ \\
\hline 0.175 & $\begin{array}{c}18 / 36 \\
(50.00)\end{array}$ & $\begin{array}{c}10 / 24 \\
(41.66)\end{array}$ & $8 / 12(66.66)$ & $26-30$ \\
\hline 0.125 & $\begin{array}{c}13 / 22 \\
(59.09)\end{array}$ & $\begin{array}{c}12 / 18 \\
(66.66)\end{array}$ & $1 / 4(25.00)$ & \multirow{2}{*}{$30-38$} \\
\hline 0.456 & $\begin{array}{c}44 / 81 \\
(54.32)\end{array}$ & $\begin{array}{c}30 / 58 \\
(51.72)\end{array}$ & $\begin{array}{c}14 / 23 \\
(60.86)\end{array}$ & \multirow{2}{*}{ Total } \\
\hline
\end{tabular}

Table 5: Showing type of bacteria which present in contaminated group. Cultures were positive, predominantly for Escherichia coli $(64 \%)$ and Streptococcus species $(80 \%)$.

\begin{tabular}{|c|c|c|}
\hline Bactrial Study & No. Of Cases & Type of Bacteria \\
\hline Negative culture & 50 cases & \\
\hline \multirow{8}{*}{ Positive culture } & \multirow{8}{*}{31 cases } & 1. Kleibsiella Spp \\
\hline & & $\begin{array}{l}\text { 2.Non Heamolytic } \\
\text { Streptococcus }\end{array}$ \\
\hline & & $\begin{array}{l}\text { 3. Pseudomonas } \\
\text { aeruoginosa }\end{array}$ \\
\hline & & 4. Staphylococcus Spp \\
\hline & & 5. Enterobacter Spp. \\
\hline & & $\begin{array}{l}\text { 6. Staphylococcus } \\
\text { aureus }\end{array}$ \\
\hline & & 7. Entercocces Spp \\
\hline & & 8. Eschrechia Coli \\
\hline
\end{tabular}

\section{Discussion}

The bacterial flora of the female reproductive tract is a focal point for the study of infectious disease in obstetrics and gynecology, as it is recognized that many pelvic infections involve bacteria resident on the cervical-vaginal epithelium. The vaginal flora contains a large variety of bacterial species, including aerobic and anaerobic organisms, as revealed by modern microbiologic methods $[14,15]$. Moreover, the diversity and kinds of organisms that comprise the vaginal microbial community vary among women [16]. Since the lower genital tract is a naturally inhabited with vaginal flora and pathogenic organisms, operative procedures through or adjacent to this field leads to a moderate to high incidence of infection. Therefore recommendations for antibiotic prophylaxis have been established in many procedures, including vaginal hysterectomy, abdominal hysterectomy, and cesarean section [17]. However, unlike most assisted reproductive techniques, these are major operative procedures that may carry a high morbidity rate from infections.

With regards minor operative procedures related to ART, such as during trans-vaginal oocyte retrieval and embryo transfer, there are no clear recommendations by any society (e.g. 


\section{Global Journal of Reproductive Medicine}

American society of Reproductive Medicine [ASRM], European Society for Human Reproduction and Embryology [ESHRE], Middle East Fertility Society [MEFS], Mediterranean Society for Reproductive Medicine [MSRM]) or evidence-based guidelines (e.g. NICE guidelines). However, these procedures have a high possibility of ascending infection from the lower genital tract to the upper genital tract, especially for those procedures that pass through the endocervical canal into the uterine cavity (e.g. intrauterine insemination and embryo transfer). Since these procedures have only small areas of tissue trauma, it is questionable whether or not antibiotic prophylaxis, the use of antibiotics for the prevention of infection, for these procedures protects against ascending infection.

Therefore, antibiotic prophylaxis might have a role to prevent infection in these procedures, but this has yet to be officially quantified. In essence, in today's evidence based medical environment, any recommendation must be built on two main questions: (1) whether ascending infections occur as a result of the procedure and (2) whether this results in a decreased pregnancy rate in such cases. Only then can a proper set of guidelines be proposed to answer this clinical query. The results of this prospective cohort demonstrated that there is limited evidence between the presence of bacterial colonies in the cervical mucus samples and the tips of embryo transfer catheters. In addition, there was an observed negative relationship between the presence of gram positive bacterial colonies and embryo implantation following embryo transfer. Even so, this trend was not observed with the presence of gram negative bacterial colonies on the catheter tips, nor gram positive or negative bacterial colonies in the cervical mucus samples.

Therefore, in accordance with the results of this study, it is recommended that if antibiotic prophylaxis is used during embryo transfer, it should mainly cover gram positive bacteria. A recent randomized controlled trial of coamoxicillin versus placebo showed that bacterial contamination of the transfer catheter during embryo transfer is associated with poor clinical outcomes. In addition, they demonstrated that antibiotics significantly reduced catheter contamination rates (49.4 versus $62.3 \%, \mathrm{RR}=0.79,95 \% \mathrm{CI}: 0.64,0.97, \mathrm{P}=0.03$ ), but there was no difference detected in clinical pregnancy rates between the two groups ( 36.0 versus $35.5 \%, \mathrm{P}=0.83$ ). Even so, there was a significant $(\mathrm{P}=0.03)$ association between the level of bacterial contamination and clinical pregnancy rates [14].

Several studies have shown a correlation between cervical mucus aspiration and increase pregnancy rates $[18,19]$. According to another study, cervical mucus aspiration with insulin syringe before embryo transfer can increase the pregnancy rate [20]. According to some reports the presence of bacterial contamination of catheter tip during embryo is evidently limited and does not significantly affect the cycle outcomes [21]. Several studies have shown that cervical mucus aspiration can decrease infection rate with E. coli, Mycoplasma, Uroplasma, Streptococcus B, D, Staphilococcus and increase implantation rate [22]. In addition to cleaning cervical mucus, other interventions, such as drug prescription (ritodrine for example) also has no significant effect on pregnancy rate [23].

\section{Conclusion}

The presence of bacterial contamination of catheter tips during embryo transfer does not significantly affect the cycle outcomes may be due to presence of mucous in cervical canal prevent ascending microorganism to endometrial cavity and avoid rough touched cervical canal and endometrium to avoid bleeding contamination of the ET catheter with mucous and or blood has been associated with expulsion or retention of embryos in the transfer set, there may be several reasons for this: mucous and/or blood may cause mechanical blockage and adherence of embryos to catheter the prospective cohort demonstrate that the presence of bacterial contamination of catheter tips during embryo transfer is evidently limited, and does not significantly affect the cycle outcomes.

\section{References}

1. Serour GI, Aboulghar M, Mansour R, Sattar MA, Amin Y, et al. (1998) Complications of medically assisted conception in 3,500 cycles. Fertil Steril 70(4): 638-642.

2. Sowerby E, Parsons J (2004) Prevention of iatrogenic pelvic infection during in vitro fertilization-current practice in the UK. Hum Fertil (Camb) 7(2): 135-140.

3. El-Shawarby S, Margara R, Trew G, Lavery S (2004) A review of complications following transvaginal oocyte retrieval for invitro fertilization. Hum Fertil (Camb) 7(2): 127-133.

4. Czernobilsky B (1978) Endometritis and infertility. Fertil Steril 30(2): 119-130.

5. Fanchin R, Harmas A, Benaoudia F, Lundkvist U, Olivennes F, et al. (1998) Microbial flora of the cervix assessed at the time of embryo transfer adversely affects in vitro fertilization outcome. Fertil Steril 70(5): 866-8670.

6. Egbase PE, al-Sharhan $\mathrm{M}$, al-Othman $\mathrm{S}$, al-Mutawa M, Udo EE, et al. (1996) Incidence of microbial growth from the tip of the embryo transfer catheter after embryo transfer in relation to clinical pregnancy rate following in-vitro fertilization and embryo transfer. Hum Reprod 11(8): 1687-1689.

7. Salim R, Ben-Shlomo I, Colodner R, Keness Y, Shalev E, et al. (2002) Bacterial colonization of the uterine cervix and success rate in assisted reproduction: results of a prospective survey. Hum Reprod 17(2): 337340 .

8. Egbase PE, Udo EE, Al-Sharhan M, Grudzinskas JG (1999) Prophylactic antibiotics and endocervical microbial inoculation of the endometrium at embryo transfer. Lancet 354(9179): 651-652.

9. van Os HC, Roozenburg BJ, Janssen-Caspers HA, Leerentveld RA, Scholtes MC, et al. (1992) Vaginal disinfection with povidon iodine and the outcome of in-vitro fertilization. Hum Reprod 7(3): 349-350.

10. Moore DE, Soules MR, Klein NA, Fujimoto VY, Agnew KJ, et al. (2000) Bacteria in the transfer catheter tip influence the live-birth rate after in vitro fertilization. Fertil Steril 74(6): 1118-1124. 
11. Peikrishvili R, Evrard B, Pouly JL, Janny L (2004) Prophylactic antibiotic therapy (amoxicillin + clavulanic acid) before embryo transfer for IVF is useless. Results of a randomized study. J Gynecol Obstet Biol Reprod (Paris) 33(8): 713-719.

12. ACOG Committee on Practice Bulletins. ACOG Practice Bulletin No. 74. Antibiotic prophylaxis for gynecologic procedures. Obstet Gynecol 2006 108(1): 225-34

13. Murray PR, Baron EJ, Pfaller MA, Jorgensen JH, Yolken RH (2003) Manual of clinical microbiology(8) American Society for Microbiology, USA.

14. Brook N, Khalaf Y, Coomarasamy A, Edgeworth J, Braude P,et al. (2006) A randomized controlled trial of prophylactic antibiotics (co-amoxiclav) prior to embryo transfer. Hum Reprod 21(11): 2911-2915.

15. Zhou X, Bent SJ, Schneider MG, Davis CC, Islam MR, et al. (2004) Characterization of vaginal microbial communities in adult healthy women using cultivationindependent methods. Microbiology $150(\mathrm{Pt}$ 8): $2565-2573$

16. Heinemann C, Reid G (2005) Vaginal microbial diversity among postmenopausal women with and without hormone replacement therapy. Can J Microbiol 51(9): 777-81.

17. American College of Obstetricians and Gynecologists Committee. Prophylactic antibiotics in labour and delivery. ACOG Practice Bulletin, clinical management guidelines for obstetrician-gynecologists 2003 : Number 47.

18. Aboul Fotouh I, Gaber al-Inany M (2008) The level of bacterial contamination of the embryo transfer catheter relate negative to the outcome of embryo transfer. Mid East Fertil Soc J 13(1): 39-43.

19. Nabi A, Awonuga A, Birch H, Barlow S, Stewart B, et al. (1997) Multiple attempts at embryo transfer: does this affect in-vitro fertilization treatment outcome? Hum Reprod 12:1188-1190.

20. Lindheim SR, DiPaola K (2010) Does transvaginal ultrasound guidance have a role in embryo transfers? Fertil Steril 94: e85.

21. Visschers BA, Bots RS, Peeters MF, Mol BW, van Dessel HJ, et al. (2007) Effect of removal of cervical mucus on pregnancy rate in IVF/ ICSI. Reprod Biomed Online 15(3): 310-315.

22. Moini A, Kiani K, Bahmanabadi A, Akhoond M, Akhlaghi A, et al. (2011) Improvement in pregnancy rate by removal of cervical discharge prior to embryo transfer in ICSI cycles: a randomized clinical trial. Aust N Z J Obstet Gynaecol 51(4): 315-320.

23. Eskandar MA, Aboa-seta Am, El-Amin M, Almushait MA, Sobande AA, et al. (2007) Removal of cervical mucus prior to embryo transfer improves pregnancy rates in women under-going assisted reproduction. Reprod Biomed Online 14(3): 308-313.

Your next submission with Juniper Publishers will reach you the below assets

- Quality Editorial service

- Swift Peer Review

- Reprints availability

- E-prints Service

- Manuscript Podcast for convenient understanding

- Global attainment for your research

- Manuscript accessibility in different formats (Pdf, E-pub, Full Text, Audio)

- Unceasing customer service

Track the below URL for one-step submission https://juniperpublishers.com/online-submission.php 